\title{
The mirror metaphor in Calvin's Institutes: A central epistemological notion?
}

\author{
Eric Kayayan \\ Department English with French and German \\ Potchefstroom University for CHE \\ POTCHEFSTROOM
}

\begin{abstract}
The mirror metaphor in Calvin's Institutes: A central epistemological notion?

In this article it will be argued that the metaphor of the mirror presents the characteristics of a central image in Calvin's Institutes of the Christian Religion. This metaphor manages to crystallize several constitutive elements of a religious epistemology which seemingly cannot be articulated in a satisfactory way without having recourse to it. As a form of dynamic accommodation, the Calvinian mirror image provokes an illumination and restores vision. It endeawours to offer a faithful reflection, even though not complete, mainly of othenwise imisible realities, thus rendering possible the knowledge thereof. "Mankind knowing itself", which becomes knowing only when it manages to emvisage itself as a mirror, is another object swbjected to the mirror 's dynamics.
\end{abstract}

\section{Introduction}

The frequent recurrence of the mirror metaphor in the French text of Calvin's Institutes of the Christian Religion, places it at the foreground of a detailed study of metaphors in the Institutes. This metaphor appears about thirty two times in the four books which constitute this work, far more often than any other single metaphor. Salient as this recurrence may be, one could legitimately ask whether it indicates anything more than a decorative figure of speech under Calvin's pen, even a possible verbal tic. One could also pretext the use of it in the Christian literature preceding the Insiltutes, in order to regard it as a dead metaphor, one that does not bring any new cognitive element to the frame where it appears. In truth, the image of the mirror in Calvin's writings has not gone unnoticed by scholars Already in 1957, Wallace noted its significance in his study on Calvin's doctrine of the Word and Sacrament (Wallace, 1957:24-27), without actually doing much more than naming it. More recently, however, the relevance of the mirror metaphor for an approach of Calvinian epistemology was pointed out by Van der Kooi (1994:385-387). He concludes an article devoted to the basic features of Calvin's theological epistemology with these words: "In binding human beings to the mirrors of God's revelation, these finally constitute the limit of human knowledge of God. For their own sake, hunian beings have to adhere 
to this limit and not go beyond it." Even though Van der Kooi indeed grants a notable importance to this metaphor with regard to the topic he tackles, he does not enter into a deeper study of its meaning, nor of its epistemological connotations. The fact that the mirror metaphor often appears in the Institutes when the issue of true knowledge is addressed, indicates in itself that there is probably more than a purely decorative aspect attached to it: the mirror image rather serves as a significant marker throughout the text and therefore calls for a more attentive look at its significance. One must immediately add that it would be exaggerated to reduce Calvin's epistemology to the study of one single metaphor, however prominent it may appear at first glance. Such an attempt would rapidly show its limits. Besides, can one speak of Calvin's epistemology, as if the Genevan Reformer had construed in his writings a well articulated theory of knowledge as part of a philosophical system? The question has already been asked, and has been answered negatively. Dowey (1984:138), supported by Van der Kooi (1994:368), wams that even though the theological universe of Calvin is a universe of knowing, and is cognitive or noetic throughout, it is probably unwise to use the term epistemology in discussing his thought, for the latter "is not rooted in an apprehension of being, a grasp of the ontic, or founded on ontological or metaphysical truth formed into propositions" (cf. also Van der Walt, 1974:369). In agreement with this statement, the use of the word "epistemology" in the present article is not to be understood in a philosophicaltechnical sense. The best way to give it some consistence here is probably to avoid speaking of a philosophical epistemology, or even of a theological epistemology, but rather to qualify it in a religious sense, as one may do with Augustine's own concern for knowledge (cf. Copplestone, 1985:51) ' 1.

The goal of the present article will thus be to examine the most significant occurrences of this metaphor within the last version of the Institutes ${ }^{2}$ by arguing

1 To speak only of the "knowledge of God" (to borrow from the titles of both E.A Dowey and T.HL. Parker's studies on this particular aspect of Calvin's thought) would also not be satisfactory here, if only because the cognitive connotations of the mirror metaphor in the Institutes cover the cognitio Dei et nostri. For a discussion of relatively recent research on the topic of Calvinian epistemology, of R C Gamble's "Current trends in Calvin research, 1982-1990" (1994:105-107).

2 The French edition, dating 1560, has been used here The text consulted is that of the C.N R S, published by J D Benoit. The relevant passages will be translated into English for the purpose of this article, using F.L Battles' translation wherever the Latin and the French text concur enough and supplying my own translation whenever needed

About references: IIl xxiv 5 - for instance - means third book, chapter twenty four, paragraph five In each quote, I used italics to indicate the topic and the vehicle of the metaphor This terminology has been used for its adequation to Calvin's pedagogical purpose when using imagery language Houever, in some of my analy ses, I rely on basic elements of M Black's theory of metaphor (Black, 1962), especially when dialing with sets of associated common places It must be noted. though. that I have purposedly 
the following: as a linguistic and rhetorical device, the metaphor of the mirror fulfils the function of a key towards knowledge, and is used as a prominent epistemologica! velicle. In refining my hasic hypothesis, I will argue that the most important elements of an epistemological connotation attached to the mirror metaphor in the Institutes are to be found in the following double connection:

- Creation as mirror of divine glory/Scripture as mirror of doctrine on the one hand

- Knowledge of God/knowledge of man on the other hand

To start with, I shall briefly contrast the mirror metaphor with that of the labyrinth in the Institutes, for the two seem to be used antithetically by Calvin. Then, after having defined the general characteristics of the mirror metaphor (notably with regard to the Calvinian theme of accommodation), a cursory approach of its link with the Paulinian mirror will be offered. A synchronic approach will be presented thereafter, in the course of which it will be attempted to arrive at some conclusions. Finally, a more general conclusion will endeavour to measure the global import of the mirror metaphor in the Instututes, calling towards further research: among others, the indebtedness of Calvin towards Augustine's theory of illumination will be discussed, as well as Calvin's position towards some Ockhamist epistemological features.

\section{Labyrinth versus mirror}

When considering the bulk of metaphors and similes in the Institutes, one can identify four general domains which give a relatively satisfactory account of Calvin's main sources when using imagery:
A. Nature, created reality
B. Products of human activity
C. Characters
D. State/condition, change of state/condition

Each of these domains could be subdivided in several sub-domains. Within the

avoidod any heavy dependence on modern theories of metaphor in my own analy ses, the reason being that my conclusions about the epistemological import of the mirror metaphor in the Insfifutes lead ne to strongly question the philosophical presuppositions lying at the core of them This unfortunately cannot be discussed here but could make the objoct of an anticle of its own 
second general domain (B), where the mirror metaphor finds its most suitable place, these sub-domains could be listed as follows:

I. buildings, shop, theatre, architecture, labyrinth, engineering structure

2. to forge, moulds

\section{3. mirror, painting}

4. food

5. filth, rubbish

6. action, verbs

7. various objects

The first of these sub-domains is probably the one which has generated the greatest interest by scholars attentive to Calvin's use of language. For instance, White (1994:309-324) has recently devoted an article to the theatre metaphor. Bouwsma (1988:69) has attributed a central meaning to the labyrinth metaphor in Calvin's psychology, arguing from a somewhat psychoanalytic perspective: according to the American scholar, it would indicate a tormented mind afraid of wandering into insoluble issues (like the doctrine of predestination, or election) and trying to counter such anxiety. Borrowing from Bouwsma - even though not adopting all his conclusions - and in terms of my basic hypothesis, I would like to suggest that this metaphor of the labyrinth presents the antithesis to that of the mirror. Therefore it deserves some brief consideration here. The following passage is noteworthy in that it precisely juxtaposes and contrasts both metaphors (it deals with the final resurrection, and the insoluble questions which many ask regarding the details of it) ${ }^{3}$ :

But since many unwary are easily caught in such allurements, and then are drawn more and more deeply into the labyrinth to the extent that when everyone fancies his own opinion there are endless disputes, the best remedy is to content ourselves, while we are still pilgrims on this earth, to see in a mirror dimly the things which we will eventually see face to face (III.xxv.11).

3 The relationshup between the Paulinian and the Calvinian use of the mirtor metaphor will be discussed hereafter It should already be noted that this passage is the only one of the thirty two occurrences which borrows directly from Paul's well known statement of I Corinthians 13:12. 
Actually the labyrinth metaphor appears about seven times in the Institutes, notably when Calvin speaks about the Trinity (I.xiii.21). It is also used, although not directly, in connection with the theme of predestination 4 :

Firstly then, let them remember that when they enquire about predestination, they enter into the sanctuary of divine wisdom, in which if someone interferes and penetrates with too great confidence and boldness, he will never manage to satisfy his curiosity and will enter into a labyrinih where no exit is to be found (III.xxi.1).

Already in 1960, Benoit (see Calvin, 1963:406; III xxi.1) noted that "Calvin likes to speak of the doctrine of predestination in terms of labyrinth" (my translation E.K.). He continued quoting several of Calvin's commentaries in order to confirm this remark. The study of this metaphor thus presents a definite interest for whoever wishes to comprehend aspects of this doctrine such as Calvin exposes it (for a discussion of Bouwsma's emphasis on Calvin's use of the words "labyrinth" and "abyss", see H.O. Oberman, 1994:127-140).

However, much more salient than the labyrinth, the metaphor of the mirror presents the characteristics of a central image in Calvinian thought. Numerically speaking, its thirty two occurrences grant it an importance superior to the labyrinth metaphor. This fact deserves some consideration if one wishes, like Bouwsma (1988) does, to confer any meaning on a metaphor in order to explore Calvin's psychology. One is tempted to say that with Calvin, the connotations of clarity and reflection of an image provided by a mirror are in opposition to the connotations of darkness and wandering linked to the labyrinth. The two first connotations attempt to offer a sufficient counterweight to the real anxiety brought about by the two last ones. This remark could be applied precisely to the doctrine of election, when envisaged under the double metaphorical sign of the labyrinth and the mirror: a deductive approach applied to the four occurences of the mirror metaphor in relation to this doctrine, makes the latter benefit from the general characteristics of the Calvinian mirror, especially when Christ as a "mirror of our election" is dealt with (cf. Van der Kooi, 1994:385-386).

\section{General characteristics of the Calvinian mirror}

The most important general remark regarding the mirror metaphor in the Institutes is the following: the link between this mirror and the well known Calvinian theme of accommodation is evident from the outset ${ }^{5}$. The mirror presents that

4 The actual topic of the metaphorical utterance here is the divine wisdom, not prodestination as such, although the two are closely related

5 Much has already been written about the theme of accommodation by Calvin La us just mention here C Ashley's doctoral thesis (1972), F W Battles' seminal article about God 
which must be seen within a limited frame. It reduces and brings down to human reach realities which otherwise would be imperceptible:

The mirror is linked to a reflecting mediation which is absolutely necessary. What one cannot directly see, he contemplates in a reflector whose materiality is the guarantee of accessibility to human nature; at the same time, this reflector is conceived and oriented in such a way that it is in the best position to capture the light waves coming from above (Kayayan, 1995:275; cf. also Van der Kooi, 1994:386).

Thus a comparative study of several occurrences of the mirror metaphor in the Institutes (mainly drawn from the first book of this work), aims at a better understanding of the nature of this mediation and its epistemological import. For each particular case presented, the following four questions must be kept in mind:

- Which object/person is spoken of in terms of mirror?

- What is reflected in the mirror?

- Who looks into the mirror?

- What is the degree of clarity of the image reflected in the mirror?

Since no similar analysis will be offered for each of the three remaining books of the Institutes, it is appropriate here to point out the main themes linked to the use of this metaphor: in book two, the mirror is mainly applied to the Bible, envisaged as Holy Scripture by Calvin (thus in line with its use in the first book). The third book associates the mirror metaphor more with Christ and the election. As for book four, the vehicle of the mirror is applied not only to the topic of doctrine, but also to the topics of sacraments and even good magistrates.

\section{The link with the Paulinian use of the mirror metaphor}

The rhetorical tradition which uses the domain of optics analogically (light, illumination, darkness etc.) in order to denote some other knowledge constantly permeates Biblical writings ${ }^{6}$. The mirror metaphor appears three times in the

accommodating Himself to human capacity (Battle, 1977:3-21); O. Millet's study of some hetoric aspects of accommodation in Calvin's writungs (1992:247-256).

6 Cf the Johannine writings in particular Thus envisaged, the first chapter of the first book of the Instrtures could be considered as an introduction to the thematics of light in that work (cf. paragraphs 2 and 3) Note as well in book 1 the title of chapter 5 (the mirror metaphor appears four times there): "The knowledge of God shines forth in the fashioning of the universe and in the continuing government of it." 
New Testament (1 Corinthians 13:12; 2 Corinthians 3:18, James 1:237) One should, however, note that of the 32 occurrences of that same metaphor in the Institutes, only two (II.vii.7 and III.xxv.11) directly refer to these passages of the New Testament. The first example recalls James 1:238. The second one, referring to 1 Corinthians 13:12 (III.xxv 11), has already been quoted. Strangely Calvin often introduces the mirror metaphor in his quotes from the New Testament, although the metaphor is actually not found in any Greek manuscript. For instance, in his commentary on chapter 15 of 1 Corinthians, Calvin makes a reference to Hebrews $11: 13$ as if a mirror were mentioned there. This actually underscores the importance which he grants to this metaphor. But he uses it most of the time in order to signify the clear and satisfying reflection of an image? Therefore, the questions which one could ask concerning the relationship existing between the Paulinian mirror and the Calvinian mirror are the following: does a discrepancy exist between their respective degree of clarity and does Calvin move away from Paul's use of the mirror metaphor (with the exception of the occurrence already quoted which refers directly to Paul's text in 1 Corinthians

? 1 Cor 13:12: "For now we see in a mirror, dimly, but then face to face Now I know in part, then I shall understand fully, even as I have boen fully understond" (RSV)

2 Cor. 3:18: "But we all, with open face beholding as in a glass the glory of the Lord are changed into the same image from glory to glory even as by the Spirit of the Lord" (KJV).

James 1:23-24: "For if any one is a hearer of the word and not a doer, he is like a man who observes his natural face in a mirtor, for he observes himself and goes away and at once forgets what he was like" (RSV).

According to Gesenius (1962:458), the word mar ah, generally used in the Old Testament with the meaning of "vision coming from God", "noctumal apparition", is once used with the meaning of "bronze mirror", in Exodus 38.8.

The mirror metaphor in Paul's epistles to the Corinthians has been studied in detail by $\mathbf{N}$ Hugeale (La inctaphore du miroir dans les Epitres de Saint Paul aux Corinthiens, Neuchatel, 1957) An English review of this study by F.W. Danker can be read in the Concordia Theological Monthly.

8 "The law is like a mirror in which we first contemplate our weakness. then the iniquity ansing from this, and finally the curse coming from buth, just as we can soe in a mirror the spots on our facc" (II vii 7).

9 Cf III xxii I "Augustıne wisely notes this: namcly, that we have in the very Head of the church a most clear mirror of free election ( . .)", cf also IIl xxiv 5 "Chnst. then, is the mirror wherein we must conicmplate our oun election And we will contemplate it there without doception". The following example (III "I) confirms the association made by Calvin between the mirror metaphior and a Paulinian text, as well as the degree of clarity and of ultimate knowledge borne by the mirror: "He also says ciseuhere that the glon. of God is visible to us in the face of Christ, and that all knowlodge is given to us in that mirror (2 Cor 46$)^{n}$ 
13:12)? At first sight, one could well think so. Doesn't l Corinthians 13:12 indeed speak of "seeing in a mirror dimly"? Inversely, we have just seen that Calvin mostly uses the mirror metaphor in order to indicate clarity and not darkness. Such a discrepancy could then be ascribed to the different materials or manufacturing techniques for mirrors respectively used in Corinth during the apostle Paul's life and during the sixteenth century. If the Hebrews had at their disposal mirrors made of polished brass, the Etruscans, the Romans and the Greeks used bronze for that purpose. Glass mirrors were introduced much later, when Venice gained fame at the eve of the fourteenth century with these: the original manufacturing technique consisted in applying an amalgam of tin and mercury at the back of a glass (Anon., 1961:3329-3300) ${ }^{10}$. However, commenting on 1 Corinthians 13:12 Fee (1987:647-648) points out the following:

The first sentence (...) is particularly relevant to their setting, since Corinth was famous as the producer of the finest bronze mirrors in antiquity. That suggests that the puzzling phrase en ainigmati [dimly] is probably not as pejorative as most translations imply. More likely the emphasis is not on the quality of seeing that one experiences in looking in a mirror - that would surely have been an affront to them - but to the indirect nature of looking into a mirror as opposed to seeing someone face to face.

Fee adds that in contemporary culture, a similar metaphor would be that of photography: as successful as it may be, it is never the thing or the person self. Actually Fee's commentary on this issue seems to concur with the Calvinian exegesis of that same Paulinian passage. In his own commentary on 1 Corinthians, Calvin stresses that the ministry of the Word, as well as the means required for the exercise thereof, are that which is compared to a mirror. God, otherwise invisible, has appointed these means in order to reveal Himself to mankind (Calvin, 1989a:429). The same applies to the structure of the universe. Thus, Calvin goes on arguing, we have to understand that the knowledge of God which we obtain through His Word is indeed true and certain, and that there is nothing in it which is confused or obscure (Calvin, 1989a:430). If, by way of comparison, one speaks of it in terms of "obscurity", it is because it is adapted to a state of imperfection and childhood. As such, it is by far inferior to the clear manifestation that one will have of it the day he will see "face to face".

10 In order to have a more precise idea of the quality of such mirrors one can consult late Middle-Age and Renaissance iconography: two paintıngs, one by Jan van Eyck (13901441) entitled "The Arnolfini wedding" (1434) and the other by Quentin Metsys (14651530) called "The banker and his wife" each grant to the mirtor a central role in their respective composition In both cases the mirror is convex. slightly curving the reflected image But it is also particularly glossy, as the light which it sends back indicates There is little doubt that Calvin, during his life, would have been able to see and admıre mirrors of great quality (for instance whlle visiting at Ferrara the duchess Rence of France early in 1536, or while being at the court of Marguerite of Valois in Nerac) 
These elements of Calvinian thought must be kept in mind if one wanis to assess the degree of clarity granted by Calvin to his metaphorical mirror. Thus, if we take Jacob as a mirror of election (III.xxii.5), we do not contemplate election in itself, but a substitute which offers to us the closest reflection of election. As such, and taking into account the framework of accommodation, this mirror is according to Calvin - worthy of being accepted with trust as offering a satisfying image of the object which one tries to reflect. The mirror can only be a mirror in so far as it cffers a reflection (even though the latter refers to an existing reality). Inversely, to seek in the mirror the essence of the very object (that is: ignoring the aspect of accommodation) would be risking to wander into the labyrinth (cf. Van der Kooi, 1994:385)

Concerning the relationship between the Paulinian mirror metaphor and the Calvinian use of that same image, one can thus conclude that certain similarities exist between the two, in spite of some difference in the perception of the mirror: this difference is due to two different historical and cultural contexts. However, in the end what counts in both cases is the difference between the reflection of an image and the real object. Less important is the quality of the image reflected in the mirror. Besides, both are referring to mirrors of great quality, if considered in their respective context.

The scope of this article does not allow me to elaborate on a diachronic comparison between the Calvinian mirror and its more recent predecessors. Some fathers of the Church (like Saint John of Damascenes) do use the mirror metaphor in their writings, as does later the Cistercian tradition (during the 11 th and 12 th centuries ${ }^{1}$ ). Special mention must be made of Augustine, in so far as two occurtences of the mirror metaphor in the Institutes are actually citations of

1 Regarding St John of Damascenes. cf "Orationes de imaginibus tres" (Scriptorium $2.5=$ 3,2 ligne 12), "Dialectica sive Capita philosophica" (Scriptorium, section 1, ligne 18) Regarding the Cistercian tradition. of for instance "The mirtor of charity" by Aelrec de Rievaulx (i990), or "The mirror of fatth" by Gullaume de Saint Thierry (1979). Here the nurror becomes the symbol of an intımate and decpenud spiritual knowledge $\mathrm{Cf}$ also, this ume in Dutch literature. "The minor of eveñnan's salvation", an anonymous piece of the 15 th century (Conly $1 /$ al, 1985) Devotional literature of this kind finds one of its highest expression in the fanous "Miroir de l'Ame Pecheresse" (contemporany of the Institutes) by Marguerite de Valois, sister of king François the first (to whom the Instırules is dedicatod). The link between Calvin and this kind of devotional literature appeats in De Jong's article "An anatomy of all parts of the soul Insights into Calvin's spirtuaiity from his Psalms commentary" (De Jong. 1994 1-14), for it has a section entitled "The mirror of the soul" De Jong (1994 3), talking about the Preface to the Psalms conmentan, writes

"The mirror metaphor, which he has twice employed, is the key to his purpose for including here, in uncharacteristically Calvinian fashion, a revien of his oun life The Psalms are the anatomy of his soul They vividly reflect the swirling, wide-ranging, sometumes conflicting and competing religious dispositions of this complex and sconsitue man of Geneva as he strove to live farthfully before the face of God " 
Augustine (l.xv.4 and III.xxii.1). In the first of these, Calvin distances himself from Augustinian anthropology: the latter takes the soul to be a mirror of the Trinity in so far as it would comprise in itself intelligence, will and memory. For Calvin, such a mirror is only a speculation, not a true reflection. On the other hand, the metaphor of Christ as " $a$ very clear mirror of free election" is described by him as "carefully considered" under Augustine's pen. The important thing to note here is that in spite of Calvin's rejection of the first of these two occurrences in its application, he seems to accept the supposed cognitive intention of the mirror metaphor such as Augustine uses it.

\section{Creation as a mirror of divine glory}

Eight of the eleven occurrences of the mirror metaphor within the gencral context of the first book of the Institutes illustrate the knowledge of God (four of them come from chapter 5 alone). This knowledge is presented as the object of wisdom in the well-known initial sentences of the Institutes:

Nearly all the wisdom we possess, that is to say, true and sound wisdom, consists in two parts: namely that in knowing God, each of us should also know himself. Besides, although the two are joined by many bonds, which one precedes and brings forth the other is not easy to discem (I.i. 1).

Here, the French text, unlike the Latin one ${ }^{2}$, structures the two kinds of knowledge by indicating in the very wording that which Calvin underlines at the end of this first chapter:

Yet, however the knowledge of God and ourselves may be mutually connected, and the one may relate to the other one, the order of right teaching requires that we first discuss what is knowing God, then proceed afterward to treat the latter (I.i. I).

As will soon become clear, the mirror metaphor in the Institutes becomes the vehicle of this double knowledge, even of the way it is structured.

In the first instance, the universe is envisaged by Calvin as a mirror in which mankind should be able to contemplate God:

Above all, we cannot in one glance survey this most artistic construction of the universe without being completely overwhelmed by an infinite brightness. It is therefore rightly so that the author of the Epistle to the Hebrews calls the universe a representation or a spectacle of thirgs invisible (Heb. 11:3) since its construction so skillfully ordered is for us a mirror in which we can contemplate God, who is otherwise invisible (1.v.1).

2 Dei cognitione et nostri 
Later, in chapter 14, God's qualities are in the same line offered to the contemplation of mankind, lhrough the mirror of creation:

There is no doubt that the Lord would have us uninterruptedly occupied in this holy meditation; that. while we contemplate in all creatures, as in mirrors, those immense riches of his wisdom, justice, gondness and power, we should not merely run over them cursorily, and immediately forget about them: but we should ponder them at length, turn them over in our minds seriously and faithfully, and recollect them repeatedly (I.xiv.21).

Thus the mirror reflecting visible things refers us to invisible realities, something which confronts us de facto with the dynamic character of its mediation. According to Calvin, these invisible realities should constitute the object of mankind's meditation. It is actually the function par excellence of this mirror: it does not merely offer a neutral reflection, but supported by this dynamic . mediation, it serves as a catalyst to human meditation.

According to Calvin, man can also find God in himself, if he tries hard enough. This illustrates the mutual connection established between knowledge of God and knowledge of ourselves:

Indeed, if there is no need to go outside ourselves to comprehend God, what pardon will the indolence of that man deserve who is loath to descend within himself to find God who lives there? (..) Thereby he nor only presents a very clear mirror of God's work in the common way humankind is governed, but he also specifies that infants, while they nurse at their mother's breasts, have tongues so eloquent to preach his glory that there is no need at all of other orators (I.v.3).

This idea is particularly stressed in chapter 15 of the first book, which deals with mankind "in its creation". There the issue of the imago Det is dealt with, among other topics:

Nevertheless, it seenis that we do not have a full definition of this 'image' if we do not see more plainly why mankind must be held in esteem, and for which prerogatives it should be deemed to be a mirror of God's glony (I.xv.4)

In the same chapter Calvin exposes the elements of his anthropology, which intends to show the connection existing between knowledge of God and knowledge of oneself ${ }^{3}$. In man's creation one finds an additional testimony of divine glory.

3 Cf I xv. I "We nust now speak of the creation of man: not only bocause among all God's work here is the noblest and most rentarkable example of his justice, uisdom. and 


\section{The mirror of Scripture}

Up to now we have had to do with occurrences of the mirror metaphor which - if one would only consider them - might lend weight to the idea that Calvin advocates a kind of natural theology: we would be in a position to gain an adequate knowledge of God by contemplating the universe, nature, mankind itself. But there is a second constituent of the meaning of the mirror metaphor in the first book of the Institutes: all the above-mentioned testimonies are insufficient, in so far as too much light actually blinds fallen mankind. Besides, paradoxically enough, this confirms the degree of clarity of the Calvinian metaphorical mirror (since a lack of light is not to blame for this state of affairs):

But although the Lord represents both himself and his everlasting Kingdom in the mirror of his works with very great clarity, such is our stupidity that we grow increasingly dull toward so manifest testimonies, and they flow away without profiting us (1.v.11).

Thus another mirror, that of Scripture or of doctrine, becomes necessary. This necessity is presented in chapters 8 and then 14 of book one (cf. Millet, 1992:208. A most interesting discussion of the possibility of a natural theology within Calvin's concept of law is offered by Hesselink (1992:62-67) in a chapter entitled "Creation and law"). In several instances throughout the Institutes, one will find this mirror of doctrine through which, Calvin argues, God reveals Himself in His Word (cf. Bates, 1992:146-147; Wallace, 1957:24-27): "In short, his [Moses'] sole Song is a clear mirror in which God appears in a manifest way (Deut. 32)" (I.viii.6).

The same metaphor appears in a slightly more developed way (followed by a simile) in chapter 14 :

In short, let us remember that God, who is invisible and whose wisdom, power and righteousness are incomprehensible, has set before our eyes Moses' history as a mirror in which he wants his likeness 10 glow' for us. For just as eyes, when dimmed with age or weakness or by some other defect, unless aided by spectacles, discem nothing distinctly; so, such is our feebleness, unless Scripture guides us in seeking God, we are immediately confused (I.xiv. 1).

It thus seems as if the argument of a natural theology is forcefully presented by Calvin, in order to enable him to demonstrate on the contrary and by means of the

goodness, but because, as we sasd at the beginning, we cannot have a clear and complete knowledge of God unless it is accompanied by a corresponding knowledge of oursclves"

About Calvinian anthropology and the way it has been assessed. of the articic of Ilavis (1994 406-118) 
mirror of Scripture (here the history of Moses) the insufficiency thereof. The mirror is indeed at the centre of the fundamental epistemological issue which consists in structuring natural knowledge and revealed knowledge. A second ordering is added, that of the knowledge of God and of man, in their mutual hierarchical relationship. This second ordering is also characterized by the same metaphor, as one can sce in the citation taken from I.xv.4: if mankind "should be deemed to be a mirror of God 's glory" because of some of his prerogatives, it is because he is the object in which this glory is reflected. An appropriate knowledge of himself is not possible if one does not take into account this divine reflection which he receives and sends back by reflecting it. Thus, for Calvinian epistemology, "mankind knowing itself' becomes such only from the moment it manages to consider itself as a mirror. Symmetrically and simultaneously though, the knowledge obtained by contemplating some human prerogatives (the very mirror) refers us to God's glory, which is perceived more distinctly by this channel. Thus the mediation of the mirror is exerted in both ways.

This illustrates the fact that the expression of these two orderings is dependent upon a factor relatıve to the mirror metaphor as a linguistic device. The topic of the metaphor is double and real: there is that which is presented in terms of mirror and that which is reflected in the mirror (the latter referring to a second real object). Actually the mirror is always something reflecting something else which comes and "inhabirs" this mirror under the form of a reflection. This second real object is invisible for mankind until it becomes visible thanks to the mediation of the mirror; that is why the latter can be described as "dynamic", since it makes something appear which otherwise could not be seen or perceived. From then on, we see two things in one and it is clear that the metaphorical mirror necessarily functions in both ways. even though the angle of exposition only indicates one of the two: in I.v.3, for instance, something divine is reflected in the government of mankind. The accent lies on the characterization of human government (it bears with it some divine characteristics). However, at the same time and symmetrically, one can look into the government of mankind in order to comprehend a particular divine characteristic and discover a reflection of it.

This underlines the fact that from the Calvinian lingustic and metaphorical view point, transcendent reality (the divine and invisible things) and immanent reality (here the human things) are indissociably linked, though without being confused.

\section{The implicit methodological precedence of the mirror of Scripture over the mirror of Creation in Calvinian epistemology}

This issue lies at the heart of the whole problematic concerning the mirror metaphor in the Institutes and deserves careful consideration at this point 
Actually, the precedence (or not) of Scripture over Creation in Calvinian epistemology has long been debated. Among others, Dowey (1965:83) writes the following:

Strictly speaking, Calvin's evaluation of these elements of the revelation in creation does not belong to his 'natural theology'. It is only from the standpoint of special revelation that one can judge properly the revelation in creation, since the fall of man.

My purpose here is to show how the study of the mirror metaphor in the Institutes confirms Dowey's appreciation, while bringing some new elements linked to the use of this specific image.

The citation taken from I.v.3 where David “(...) presents a very clear mirror of God's work in the common way humankind is governed (...)" is rather ambivalent once considered from the perspective of the distinction between natural revelation (via Creation) and special revelation (via a revealed Word). Here Calvin implicitly maintains that this very clear mirror is presented to us by the Word of God expressed by David. By making such a reference to a Biblical writing at this very moment of his argument ${ }^{14}$, and taking into account the status of special revelation which he grants to Biblical writings, he implicitly argues that a knowledge of God through some other aspect of the universe, becomes clearly accessible to mankind only once exposed in the special revelation. The first mirror (of Creation) needs the second one (Scripture) so that what it reflects can be rightly assessed for what it is, even though this first mirror existed before the second one has appeared ${ }^{15}$.

The above-mentioned ambivalence is illustrated by two other passages of this chapter five. They will lead us to a deeper appreciation of the significance of the mirror metaphor for our issue: "And certainly however much the glory of God shines forth, scarcely one man in a hundred is a true spectator of it!" (I.v.8).

The twofold question asked here is the following: Where, and by whom can one find such a knowledge, if "scarcely one man in a hundred is a true spectator" of God's glory? Can it even be said that such a knowledge exists? The second

14 We must note that Calvin has not yet started tackling the issue of the divine ongin of the Bible as special revelation: this will only take place in the next chapter

15 However, according to McGrath (1990 153), Calvin does not make any call to a specifically Chnstian source of revelation dunng the first chapters of the Institules His line of argument is basod on an empirical observation and reasoning If Calvin introduces Biblical citations, it is in order to consolidate a natural general knowicdge of God, rather than establishing this knowledge in the first instance. The study of the mirror metaphor in this context forces me, however, to doubt wiether this is indeed the case 
citation brings an answer to this question and again introduces the mirror metaphor:

For this reason, the apostle, in that very passage where he calls the worlds the images of things invisible, adds that through faith we understand that they have been fashioned by God's word (Heb. 11:3). He means by this that even though God's invisible majesty is made manifest by such mirrors, we have not the eyes to see this unless they be illumined by the inner revelation given from above (I.v.13).

For Calvin, such a knowledge is the fruit of faith, and he discloses in the very method of his exposition an essential aspect of his basic presupposition, namely that a knowledge of God characterized by faith precedes any other true knowledgc. The fact that the two citations of Hebrews 11:3 (I.v. I and I.v.13 just quoted) are accompanied by the mirror metaphor, as well as the way in which this is done, illustrate that point: the first citation occurs at the very beginning of chapter 5 , the second at the very end of it. The metaphor seems to be used both times with the same connotations. However, whereas the first time the idea of a knowing faith is absent of it (the quote of Hebrews 11:3 is so to speak truncated $\left.{ }^{16}\right)$, the second time this idea is restored "(...) the apostle, in that very passage where he calls the worlds the images of things invisible, adds that through faith we understand that they have heen fashioned by God's word (...)". This idea can now lead to the next chapter ("Scripture is needed as guide and teacher for anyone who would come to God the Creator").

Within chapter 5, Calvin has created an artificial gap between the two occurrences of the quotation of Hebrews $11: 3$ in order to argue that no true knowledge is possible unless the second pole be reached (the pole of faith leading to Scripture). Unless this pole be reunited with that of natural knowledge, a fundamental insufficiency will always remain. The role played by the mirror metaphor in this way of reasoning is the following: as already noticed, this insufficiency comes from an excess of light reflected in the different mirrors presented to us ${ }^{17}$. But this light is precisely what leads us towards the invisible, God, whom man should contemplate after having contemplated the "construction of the universe". How can one paradoxically move from a light blinding and

16 "The reason why the author of the Letter to the Hebrews elegantly calls the universe the appcarance of things invisible (Hcb 11 3) is that this skillful ordering of the universe is for us a mirror in which we can contemplate God, who is otherwise invisible "

17 Cf. I.v.I Cf. also I v 13: "It is therefore in vain that so many buming lamps shine for us in the workmanship of the universe to show forth the glon of its Author Although they bathe us wholly in their radiance, vet they can of themselves in no way lead us into the right path Surcly they strike some sparks, but before their fuller light shines forth, they are smothered." 
infinite to the invisible God who lets Himself be contemplated? Is such an accommodation possible? It is possible, but only through the mediation of a "mirror" of which the nature, in the Calvinian metaphorical use of it, is to offer a much deeper perspective than the mere reflection of what is (the latter only blinds us). Actually, this mediation operates a transformation which changes the content of the vision, reshaping it, so to speak. In which way? By the passage of one mirror to another one. There are indeed two mirrors presented in Calvin's writings: the one offering as clear a reflection as the other (Creation and Scripture). Both should be approached by faith. They reflect the same object and should logically be one and same mirror. However, the first of them, without having lost anything of its clarity, is not accessible to eyes which have become "rheumy" (in French: chassieux). In other words, the glory of God whose reflection should be seen in the mirror of Creation, is not perceived by mankind anymore. Therefore, the mirror of Scripture discloses in a totally satisfying manner the image reflected by the previous one. For which reason is it now a satisfying reflection? Because, Calvin says, it is "the mirror in which God wants his image to shine forth for us" (I.xiv. I) ${ }^{18}$. In the case of the mirror of the works of Creation contemplated by mankind without the help of Scripture, the "perversity of our judgement" can become the rule, whereas in the case of God's works presented in the mirror of Scripture, "they are considered as is right and proper, namely by the immutable truth which is the rule of them" (I.vi.3) ${ }^{19}$. It is thus in agreement with his own methodology that Calvin speaks first of Creation as a clear mirror of divine glory, since in order to do so he leans on the illumination which he implicitly attributes to the mirror of Scripture: he quotes the latter and leans on it before even presenting it as illuminating.

For Calvin, accommodation is effected by the mediation of the mirror of Scripture, which communicates to the first mirror a now visible reflection of divine glory. According to him, the problem is a deficient human vision which must be compensated for, not the objective deficiency of the reflection offered by the mirror of Creation. Only an illumination taking place via the mirror of

18 Cf.I.vi.2. However, couldn't this mirror of doctrne also be made obscure, like the prenous one? At the beginning of the same paragraph, Calvin insists on the certainty of the doctrine imprinted into the heart of the divine ministers: God confirms His Word and makes it constantly known throughout the ages Morcover, Calvin exposes his doctrine of the intermal testimony of the Holy Spirit as one of the forms of this confirmation ("ratlfication")

19 Not following this order would be nsking to fall back into the labyrinth "If we turn aside from the Word, as I have just now sard. though we may strive with strenuous haste, yet, since we have got off the track. we shall never reach the gaal For we should so reason that the splendor of the divine countenance. which even the apostle calls "unapproachable' (1 Tum 6:16) is for us like a labyrinth which tangles us up from all sides. if we do not have the Word to direct us" (I vi.3) 
Scripture accepted by faith allows to compensate for such a deficiency. Thus the dynamic aspect of this mirror is confirmed since it brings inore than a mere reflection - it provokes an illumination. We can therefore note that a split between two kinds of vision has taken place: the first one, which one could describe as "natural", perceives only the object of the mirror of Creation, without seeing the reflection which shines forth through it; the second, illuminated, unites in the same vision the mirror and what it reflects.

A last example taken from the first book of the Institutes reinforces my contention, namely that Calvin does not present the mirror of special revelation in a diachronic way, but that the latter is the necessary counterpoint for any enlightened human look at the world. Not only the visible things of Creation are a mirror in which man can contemplate God, but the heavenly spirits themselves, whose ministry God uses in order to communicate to human beings, fulfil this function:

For it would not be reasonable to pass over without honor those instruments through which God particularly shows forth the presence of his divine majesty. Likewise, on this account they are more than once called gods, because in their ministry as in a mirror they in some respect exhibit his divinity to us (I.xiv.5).

For Calvin, such creatures reflect the image of God in so far as they carry His Word in a special way.

We have seen that the mirror is not neutral, but that its function is to prompt mankind to meditate; it is even used as a catalyst for such a meditation. This active role of the mirror takes its full import during the dynamic passage which man is invited to effect - through the resulting illumination - from the first mirror to the second. Truly, the great majority of the remaining occurrences of the mirror metaphor in the Institutes will only be an extension of this mirror of doctrine, applied to some particular themes which Calvin wants his reader to meditate upon.

\section{Conclusion}

Before attempting a cursory comparative assessment of Calvin's religious epistemology in the light of the mirror metaphor in the Institutes, I shall summarize four main connotations which, it has been suggested, characterize the metaphorical mirror globally envisaged:

* This mirror, particularly that of Scripture, implies accommodation: it is first the means by which any human vision of invisible things is made possible. Moreover, it gives a frame to this vision, it detennmes the limits of the latter 
(they are adapted to human limits). It also offers a faithful reflection of the things reflected.

* The mirror possesses a dynamic character, transforming the vision by an illumination; it actually allows recovery of a lost vision. This dynamic character stimulates meditation.

* One can perceive two things in this mirror: from this conjunction derives a close association of realities which, however, have a different ontological status. One could say that this generates a definite optimism as to the possibility of knowing more, once this association is established. The anxiety of finding oneself trapped into the labyrinth has therefore been exorcized.

* "Mankind knowing itselt" becomes knowing only whell it manages to envisage itself as a mirror. Mankind receives in itself the reflection of something else and at the same time points towards that "something else" by sending back the reflection. Far from envisaging for man a status of autonomy, Calvin, by placing him within the boundaries of his metaphorical mirror, ascribes to him the domain of his cognitive activity: neither limited to the dimensions of a mirror's frame where he would not read any transcendent reflection anymore, nor the absolute possessor of a reflection which exceeds him, even though it inhabits him. Thus, it seems that both secularist and mystical poles are avoided in this "neither ... nor ..." position.

Thus envisaged, the metaphor of the mirror in the Institutes presents a remarkable linguistic phenomenon, in so far as it manages to crystallize and present several constitutive elements of a religious epistemology which seemingly cannot be articulated in a satisfactory way without having recourse to that metaphor: it regularly appears during the main moments of the exposition of themes related to a knowledge of a superior kind. Therefore one can say in that sense that this metaphor plays a central role in John Calvin's religious epistemology. The latter breaks with Platonic epistemology, even though at the start it uses the same vocabulary (light, blindness provoked by the sensible reality): the shadows perceived in relation with the transcendent reality of pure ideas are replaced by a trustworthy reflection, in so far as it is the result of an illumination. This illumination replaces the ascending way towards the Ideas which, according to Plato, is the prerogative of philosophy via dialectics and mathematics (Brun, 1988:43-44). As such, sensible reality is not deceitful. Once the illumination has occurred, it is not a matter of avoiding this reality but - on the contrary - of observing it with more attention than ever, both for what it is and for what it reflects, the two being inseparably linked together. For sure the illumination does not allow to contemplate face to face totally transcendent realities, but it brings them down to human range. The knowledge which we can have here is 
satisfying, even though still limited and in any case always in a kind of expectation.

The role of the visual element in Calvin's epistemology, as opposed to the auditive one, is at stake here and the study of the mirror metaphor makes it possible to discem better its proper place. Torrance (1965:140-160), in a significance article on "Knowledge of God and speech about Him according to John Calvin", has stressed the fact that partly under the influence of John Major (deemed to have been one of Calvin's teachers at the College of Montaigu in Paris, himself very much indebted to Duns Scott) Calvin's intuitive knowledge of God is intuitiva auditio, intuitive auditive knowledge arising in and through God's Word. Torrance (1965:150) is worth quoting at this point of the discussion:

Even Major insisted on thinking through the problems of perception in our natural knowledge in terms of hearing as well as seeing - this means, as Calvin must have realised through Major's teaching, that the place of vision in our knowledge has but a limited range and that perceptibility cannot be taken as the final criterion of intuitive evident knowledge. There is no point, of course, in rejecting the proper place of vision in theological knowledge, but it cannot be allowed to dissolve away the auditive element, which is basic and essential.

Here, the extent to which Calvin could have been influenced by Augustine's theory of illumination is at stake. Torrance argues against such an influence. For the Scottish theologian, the Greek emphasis on the centrality of the visual aspect for cognition permeates Augustine's idea of the Logos. This emphasis manifests itself, among other forms, as follows:

In the Augustinian outlook nature was looked at only to be looked through toward God and the eternal realities. As such it had no significance in itself but had a significance only in so far as it reflected heavenly patterms and was moved by an immanent longing for them (Torrance, 1965:142).

In contradistinction, Calvin, gripped by a Biblical doctrine of the Word, would have insisted that knowledge of God is reached primarily by hearing rather than by seeing (Torrance, 1965:150)20. Without denying the Calvinian insistence on intuitiva auditio, it remains to be seen whether Calvin owes nothing to Augustine's theory of illumination and whether the metaphorical mirror does not

20 According to Torrance, Major "failed to think this out to the end, for in the last analysis he tended to lapse into the Augustunian notion of vision". It must be noted that Torrance's article has been criticized on at least one side: Dowey (1984:138) reproaches him for not paying any attention to the Calvinian principle of accommodation, and not offering a single citation of Calvin's work 
offer here a reformed version of such a theory 21 . Commenting on Psalm 36 verse $9 \mathrm{~b}$ ("In thy light do we see light"), Calvin (1989b:12) writes:

The metaphor of light (...) is tacitly most emphatic, denoting that men are altogether destitute of light, except in so far as the Lord shines upon them. If this is true of the light of life, how shall we be able to behold the light of the heavenly world, unless the Spirit of God enlighten us? For we must maintain that the measure of understanding with which men are by nature endued is such that 'the light shineth in darkness, but the darkness comprehendeth it not', (John 1:5) and that men are enlightened only by a supernatural gift (...)

I would like to suggest that the Calvinian version of the theory of illumination combines the visual aspect of cognition and the intuitiva auditio by means such as the mirror metaphor, since the latter is applied to Scripture as Word: Word heard, but destined to provoke an illumination, restore vision and change the look of mankind on the whole of reality.

However, the relevance of this study does not only stem from the link with Augustine, but also from the links between Calvin and late Scholasticism, particularly the Ockhamist tradition22. Here again, Torrance (1965:152) offers an important departure point:

In his doctrine of intuitive perception Ockham denied that the mind operates with media between it and objects that are somehow copies of those objects. We apprehend objective realities directly, not by means of some sensible or intelligible species in medio.

The question which I should like to ask with regard to the metaphorical mirror in the Institutes is the following: Did Calvin replace the species in medio rejected by Ockham, by the speculum in medio, the mirror in the middle, the second not being an ontological category, but the only linguistic means to denote the cognitive contact of the restored human mind with true knowledge?

I shall conclude by saying that a deeper philosophical study of the mirror metaphor within Calvinian epistemology could shed light more adequately on the

21 Augustine accepted that "we cannot perceive the immutable truth of things unliss they are illuminated as by a sun This divine light, which illumines the mind, comes from God, which is the 'intelligible light', in whom and by whom and through whom all things which are luminous to the intellect become luminous" (Copplestone, 1985:62, cf. also 63-67)

22 The issue of late mediaeval influences upon Calvin has been dealt with by McGrath in a very well documented article Cf in particular the issue of Calvin's aligning himself with the via nominalium, under the form of the schola Augustimana moderna (McGrath, 1992:21-22). 
way the constitutive elements of this metaphor relate to each other. By drawing more systematic conclusions, such a study would allow one to appreciate better the uniqueness of Calvin's views in this domain, not only in relation with Plato, Augustine or Ockham, but also with Descartes and the English philosophical school of the seventeenth and eighteenth centuries. Ultimately, the Calvinian contribution should help us to reassess the Enlightenment and its rationalism against what seems to be a genuine form of Christian Enlightenment.

\section{Bibliography}

ANON. 1961. Mirror. (In Universal World Reference Encyclopedia, 9:3329-3300.)

ASHLEY, C. 1972. John Calvin's utilization of the principle of accommodation and its continuing significance for an understanding of the principle of Biblical language. Fort Worth, Texas : Southwest Baptist Theological Seminary (Unpublished Ph. D dissertation.)

BATES, G. 1992. The typology of Adam and Christ in John Calvin (In Gamble, R C, ed Articles on Calvin and Calvinism, vol 6 New-York: Garland Publishing, Inc p. 146162.)

BATTLES, F.L 1977 God was accommodating Himself to human capacity. Interpretation, 28:3-21.

BIBLE 1952 The Bible, containing the Old and New Testaments Revised Standard Version New York: American Bible Society

BLACK, M. 1962 Metaphor. (In Black, M Models and metaphors: Studies in language and philosophy. Ithaca : Cornell University press. p. 25-47.)

BOUWSMA, W.J 1988. John Calvin A sixteenth century portrait Oxford : University Press

BRUN, J 1988 L'Europe philosophe. 25 siècles de pensée occidentale Paris Stock.

CALVIN, J. 1963. Institution de la religion chretienne Edition critique avec introduction, notes et variantes publiee par Jean-Danicl Benoit. Paris : J Vrin

CALVIN J. 1989a Commentary on the Epistles of Paul the Apostle to the Corinthians. Translated from the original Latin, and collated with the author's French version, by the Rev John Pringle Volume one Grand Rapids, Michigan Baker Book House

CALVIN, J. 1989b. Commentary on the Book of Psalms, translated from the original Latin, and collated with the author's French version by the Rev.J Anderson Grand Rapids, Mich : Baker Book House

CONLEY, J., DE BAERE, G \& SCHAAP, H J C. 1985. The mirror of everyman's salvation A prose translation of the original Everyman Amsterdam Rodopi

COPPLESTONE, F 1985. A history of philosophy New York: Image Books Doubleday.

DANKER, F W. 1960 Review of Hugedé, R 1957 la métaphore du miriur dans les Epitres de Saim Paul aux Cormthians. Concordia 7heological Momthly, 31 $428-429$

DAVIS, T J 1994. "Not hidden and far off" The bodily aspect of salvation and its implications for understanding the body in Calvin's theology. Calvin Theological Journal, (29)2:406-418, Nov 
DE JONG, J.A. 1994. "An anatomy of all parts of the soul": Insights into Calvin's spirituality from his Psalms commentary. (In Neuser, W.H. ed. Calvinus Sacrae Scripturae Professor. Grand Rapids, Michigan : Eerdmans. p. 1-14)

DE RIEVAULX, Aelred. 1990. The mirror of charity. Translated by Elizabeth Connor. Introduction and notes by Charles Dumont. Kalamazoo, Mich. : Cistercian Publications.

DE SAINT THIERRY, Guillaume. 1979. The mirror of faith. Translated by Thomas X. Davis Introduction by E. Rozanne Elder. Kalamazoo, Mich. : Cistercian Publications.

DOWEY, E A. 1965. The knowledge of God in Calvin's theology New York : Columbia University Press.

DOWEY, E.A. 1984. The structure of Calvin's theological thought as influenced by the twofold knowledge of God (In Neuser W.H, ed. Calvinus Ecclesiae Genevensis Custos. Frankfurt : Verlag Peter Lang. p 135-148.)

FEE, G.D. 1987. The First Epistle to the Corinthians Grand Rapids, Michigan : Eerdmans

HESSELINK, I.J. 1992 Calvin's concept of the law. Allison Park, Pennsylvania : Pickwick Publications.

GAMBLE, R.C. 1994 Current trends in Calvin research, 1982-1990. (In Neuser, W.H. ed. Calvinus Sacrae Scripturae Professor. Grand Rapids, Michigan : Eerdmans. p. 91-112)

GESENIUS W. 1962. Hebraisches und Aramaisches Handworterbuch über das alte Testament. Berlin : Springer-Verlag

KAYAYAN, E. 1995. Accommodation, Incarnation et Sacrement dans l'Institution de la Religion Chrétienne de Jean Calvin. l'utilisation de métaphores et de similitudes. Revue $d$ 'Histoire et de Philosophie Religieuses, 75(3) 273-287, Jul., Aug., Sep.

$\mathrm{KJV}=$ King James Version

See

THE HOLY BIBLE

McGRATH, A.E. 1990 A life of John Calvin Basil Blackwell : Oxford.

McGRATH, A.E. 1992. John Calvin and late mediaeval thought A study in late mediaeval influences upon Calvin's theological development. (In Gamble, R C., ed. Articles on Calvin and Calvinism, vol 4 New-York: Garland Publishing. Inc p. 14-34.)

MILLET O. 1992. Calvin et la dynamique de la Parole. Etude de rhétorique réformée Paris: Honoré Champion

OBERMAN HA 1994 Initia Calvini: The matrix of Calvin's Reformation (In Neuser, W.H ed. Calvinus Sacrae Scripturae Professor Grand Rapids, Michigan : Eerdmans. p 113-154.)

PARKER, T.H.L 1959. Calvin's doctrine of the knowledge of God Grand Rapids, Mich. Eerdmans

RICHARDS, IA. 1936. The philosophy of rhetoric Oxford : Oxford University Press

$\mathrm{RSV}=$ Revised Standard Version

See

BIBLE, 1952.

SCRIPTORIUM 1993 Copyright by Darl, J, Dumontand Randall, M Smith 
THE HOLY BIBLE. n.d Authorized (King James) Version South Holland, Illinois : The World Home Bible League

TORRANCE, T.F. 1965 Knowledge of God and speech about Him according to John Calvin. (In Regards Contemporains sur Jean Calvin. Actes du Colloque Calvin Strasbourg 1964. Paris : Presses Universitaires de France. p. 140-160.)

VAN DER KOOI, C. 1994. Within proper limits: Basic features of John Calvin's epistemology. Calvin Theological Journal, 29(2):364-387, Nov.

VAN DER WALT, B J. 1974. Die Natuurlıke Teologie met besondere aandag aan die visie daarop by Thomas van Aquino, Johannes Calvyn en die "Synopsis Purioris Theologiae". 'n Wysgerige ondersoek Potchefstroom : PU vir CHO. (Thesis - D.Phil.)

WALLACE, R S. 1957. Calvin's doctrine of the Word and sacrament Grand Rapids, Michigan : Eerdmans.

WHITE, R 1994. Theatrum Mundi: the Theatre Metaphor in Calvin. Australian Journal of French Studies, 31 (3):309-324, Sep.-Dec. 
